Proc. Estonian Acad. Sci. Geol., 2005, 54, 1, 26-39

\title{
Eskers in the periphery of their distribution in North Estonia
}

\author{
Reet Karukäpp \\ Institute of Geology at Tallinn University of Technology, Estonia pst. 7, 10143 Tallinn, Estonia; \\ karukapp@gi.ee
}

Received 26 January 2005, in revised form 1 February 2005

\begin{abstract}
Eskers are frequent landforms in the palaeo-glacial erosional zone. A channelized network of subglacial water conduits above the nonpermeable surface is an obligatory precondition for esker genesis. The current study supports the results of the investigations of modern high-arctic esker formation. The structure and stratification of the esker deposits indicate fast changes and alternation of erosion-transport-accumulation processes. The extent of esker systems over tens or hundreds of kilometres indicates their time-transgressive inherited genesis.

The territory of Estonia lies in the periphery of the esker distribution area of the Scandinavian glaciation. Radial eskers in Estonia consist mainly of coarse-grained deposits of local Palaeozoic bedrock. The combination of eskers and glaciokarst kettle holes or glaciofluvial plateaus and kame fields is frequent. The ridge-like glaciofluvial topography, morphologically similar to eskers but formed in stagnant ice is specified as crevasse fillings, and is genetically related to kames.
\end{abstract}

Key words: eskers, Scandinavian glaciation, glacial topography, lithology, Late Weichselian.

\section{INTRODUCTION}

The ridge-like morphology of eskers has so far served as the main criterion in the study of these landforms. In this paper genetical differences of eskers and kame fields or single kames of ridge-like form and their relations with glacier dynamics are discussed. Attention is drawn to the dependence of esker formation upon the subglacial surface and glacier hydrology. The most characteristic feature of the distribution of eskers is their occurrence in the centres of both the Scandinavian and Wisconsin glaciation areas.

The term "esker" (eiscir in Irish, ås in Swedish, oos in Estonian) refers to elongated sinuous ridges of glaciofluvial gravel and sand. Eskers are the infillings of ice-walled stream channels, and may record deposition in subglacial, englacial 
or supraglacial drainage networks. A general genetic classification of eskers proposed by Warren \& Ashley (1994) recognizes the following basic types: 1) tunnel fills, formed in englacial and subglacial conduits, and exposed by glacial ablation; 2) ice channel fills, deposited in subaerial ice-walled channels; 3) segmented tunnel fills, formed by pulsed glacier retreat; and 4) beaded eskers, consisting of successive subaqueous fans deposited during pulsed retreat of the water-terminating glacier.

The topography of eskers is extremely variable, and can take the form of single continuous ridges of uniform cross-section, single ridges of variable height and width, single low ridges linking numerous mounds or beads, or complex braided systems of esker ridges. Most eskers and esker systems are aligned subparallel to palaeo-ice streams (radial eskers). Some eskers are aligned transverse to the former ice flow (initiated by subglacial moraines and transverse crevasses).

\section{ESKERS AND SUBGLACIAL SURFACE}

The main precondition for esker formation is considered to be the rigid nonpermeable subglacial surface (Punkari 1994, 1997; Boulton et al. 1996). When an about $300 \mathrm{~km}$ wide belt of wet-based glacier was located on solid subglacial rocks (igneous rocks, limestones, dolomites), drainage channels were formed under the ice. The formation of eskers depends on the subglacial or englacial drainage system. According to the lithology of the subglacial surface the drainage systems are divided into discrete and distributed systems (Benn \& Evans 1998). The discrete drainage systems, the so-called R-channels (Röthlisberger 1972) - incised up into the ice - are necessary for esker formation. The genesis of the eskers following a valley bottom was probably connected with the subglacial N-channel incised into substratum (Nye 1973).

The hydraulic gradient and direction of flow were mainly controlled by the ice surface topography. As a result, some eskers do not follow the subglacial slope topography. Subglacial conduits had a complicated dendric pattern. The eskers accumulated and preserved only in the main channels. The deposits from tributaries were most likely eroded in the course of deglaciation. When the subglacial surface consisted of unconsolidated sediments and had the distributed drainge system, the meltwater drained as groundwater and no favourable conditions for esker formation were created (Benn \& Evans 1998).

\section{ESKERS AT MODERN GLACIER MARGINS}

Compared to palaeo-glacier landforms, eskers at high-arctic glacier margins are rather modest in size. The possibility of observing the process of esker formation directly in front of the high-arctic glaciers (Huddardt et al. 1999) gave 
an important analogue for glaciofluvial sedimentation of the palaeo-glacier. The esker described by these authors is developing in the suture of two Vegbreen glacier lobes on Southwest Spitsbergen. Detailed morphological and lithological investigations suggest that the evolution of the esker passes through several stages. The final morphology and structure are mostly designed by erosion and slumping, flow and block failure along the ridge flanks, and therefore esker is a destructional form rather than a constructional one (Huddardt et al. 1999). If the processes in Late-Glacial time were similar, we certainly overestimate the morphology and structure of eskers for their genetic definition.

\section{ESKER LANDSCAPES IN ESTONIA}

Eskers are considered to be the most typical landforms in Estonia (Raukas 1998), attractive due to their morphology. A great number of ancient myths and folk-tales are known about personified esker formation (Eilart 1988). Most of them describe the genesis of eskers and accompanying depressions as the result of the activities of the Estonian epic hero Kalevipoeg (ploughing furrows, places for resting or sleeping, footprints of his horse, etc.). The Lithuanian authors G. Motuza and V. Motuza (1999) called attention to the localization of the Kalevipoeg legends in Upper Estonia (situated above the highest shoreline of the Baltic Ice Lake). They concluded that these legends originated from the tribes who lived about 10 000-12 000 years ago and were witnesses of rapid changes (slope processes, thermokarst phenomena, fluctuation of water level) in landscape evolution. These legends changed with time, incorporating the typical details of every epoch, for example horse and ploughing from the Iron Age. A number of steep-sloped eskers served as the Iron Age stronghold hills. Owing to their characteristic bed-and-pillow shape, these eskers were named as beds of Kalevipoeg.

The 23 most picturesque eskers are registered in the Estonian Book of Primeval Nature (Pirrus 1997). Their detailed description includes topographic maps, morphological characteristics, geological data, status of protection, possible recreation value of the landscape, and recommendations for management.

\section{THE DISTRIBUTION AND MORPHOLOGY OF ESKERS}

Esker systems are concentrated close to the centres of the last, Weichselian glaciation in Sweden, Finland, Karelia, and North Estonia (Fig. 1), and Wisconsin glaciation in Canada and Northern and Northeastern United States. No authentic data are available about eskers of previous glaciations. As the eskers of the last glaciation are associated with the areas of glacial erosion, they were probably eroded and incorporated in subglacial till. 


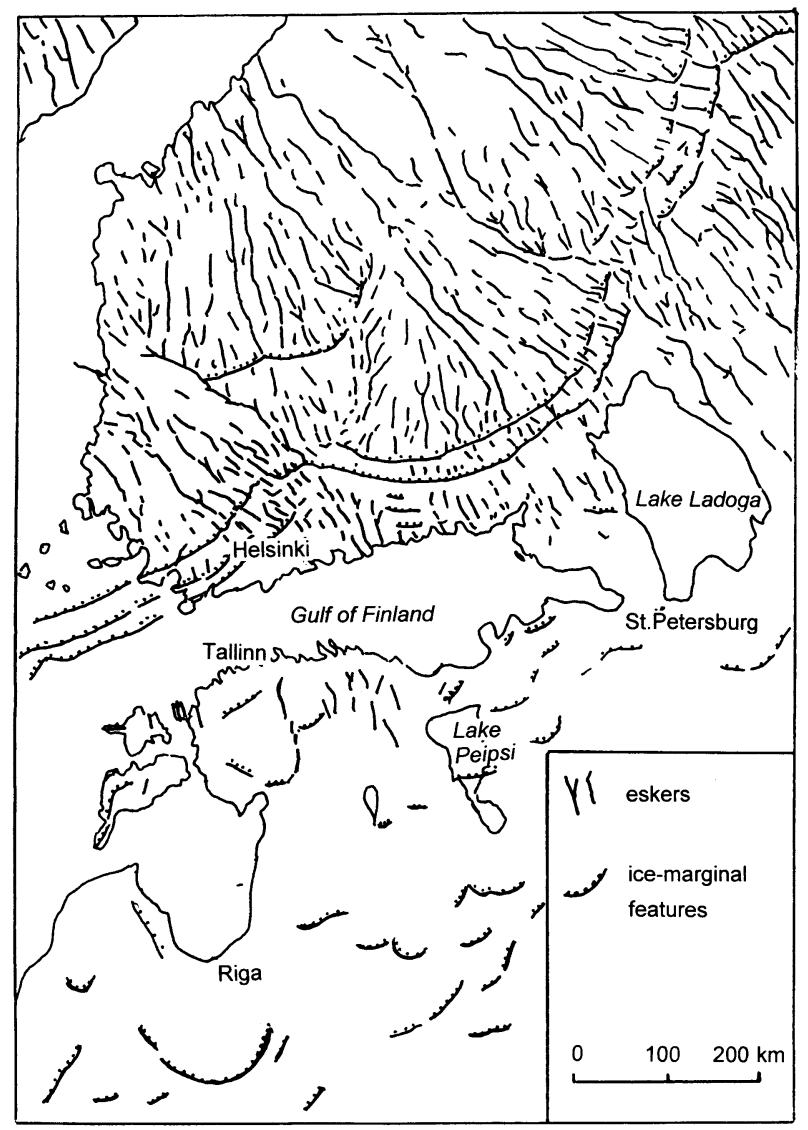

Fig. 1. Eskers and ice-marginal features of the Scandinavian Ice Sheet (after Punkari 1997 with author's complements). North Estonia is a peripheral zone of the esker distribution.

Eskers in Estonia (Fig. 2) are located mostly in the northern part of the territory and are associated with the bedrock consisting of Palaeozoic limestone and dolomite. Only few small valley eskers can be found in the Devonian sandstone area (Sakala Upland). Typical eskers do not occur in Latvia, Lithuania and farther to the periphery of the palaeo-glacier.

The Pandivere Upland has the greatest concentration of eskers in Estonia. The largest esker systems of Neeruti-Vägeva-Rakke (Fig. 2: 1) and Pikasaare-Tapa (Fig. 2: 2) have the lengths of about $50 \mathrm{~km}$ and $40 \mathrm{~km}$, respectively. The total length of the eskers in the Pandivere Upland is about $230 \mathrm{~km}$ (Karukäpp 1978).

A considerably long (about $80 \mathrm{~km}$ ) complex of eskers and associated formations including kames, hummocky moraine, and small deltas extends in the $\mathrm{N}-\mathrm{S}$ direction from Saku to Eidapere (Fig. 2: 3). It marks a suture area between two palaeo-ice lobes. 


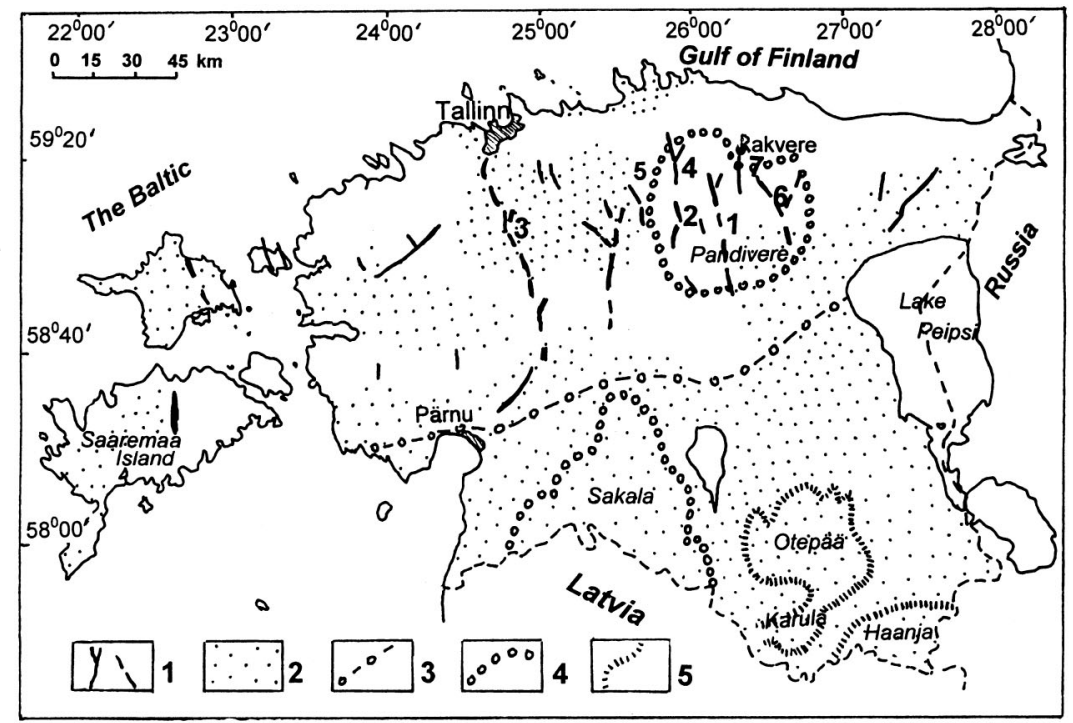

Fig. 2. Eskers against the background of the thickness scheme of Quaternary deposits. 1, eskers; 2, thickness of Quaternary cover exeeds $5 \mathrm{~m}$; 3, northern border of Devonian sandstone outcrop; 4 , foot line of glacial erosional upland; 5 , foot line of glacial accumulative heights. The numbers on the map mark the eskers and esker systems mentioned in the text: 1, Neeruti-Vägeva-Rakke; 2, Pikasaare-Tapa; 3, Saku-Eidapere; 4, Viitna; 5, Aravete; 6, Mõdriku-Paasvere; 7, Pahnimägi.

The morphology and structure of the eskers in Estonia was investigated in more detail by Endel Rähni, Anto Raukas, and Avo Miidel in the 1960s in the frame of the study of North Estonian glacial marginal formations (Raukas et al. 1971). The morphological classification distinguishes eskers according to their longitudinal profiles, shape of cross-section, symmetry or asymmetry of slopes (Rähni 1957). Rähni subdivided the North Estonian eskers into narrow (width to height ratio up to $7: 1$ ) and wide ones (over $7: 1$ ). Small, short eskers in the esker systems were called esker cones (Rähni 1967). Two or more eskers, usually situated in a line, make up an esker chain. The eskers, positioned irregularly or parallel to each other, constitute an assemblage of eskers. Several esker assemblages with similar morphology, structure, and genesis form an esker group. When several esker groups have been formed within a uniform glacier channel or crevasse system, the complex of eskers is termed as esker system.

The relative height of North Estonian radial eskers reaches 40 m (usually 10$15 \mathrm{~m}$ ). Narrow radial eskers have steep slopes (up to $40^{\circ}$, generally $20-30^{\circ}$ ), while wide eskers have gentler slopes.

The kettle holes of glaciokarst origin - esker depressions - are typical North Estonian eskers. Rähni $(1957,1967,1984)$ pointed to the regularity of their position relative to eskers. The kettles are situated on the eastern or southeastern 


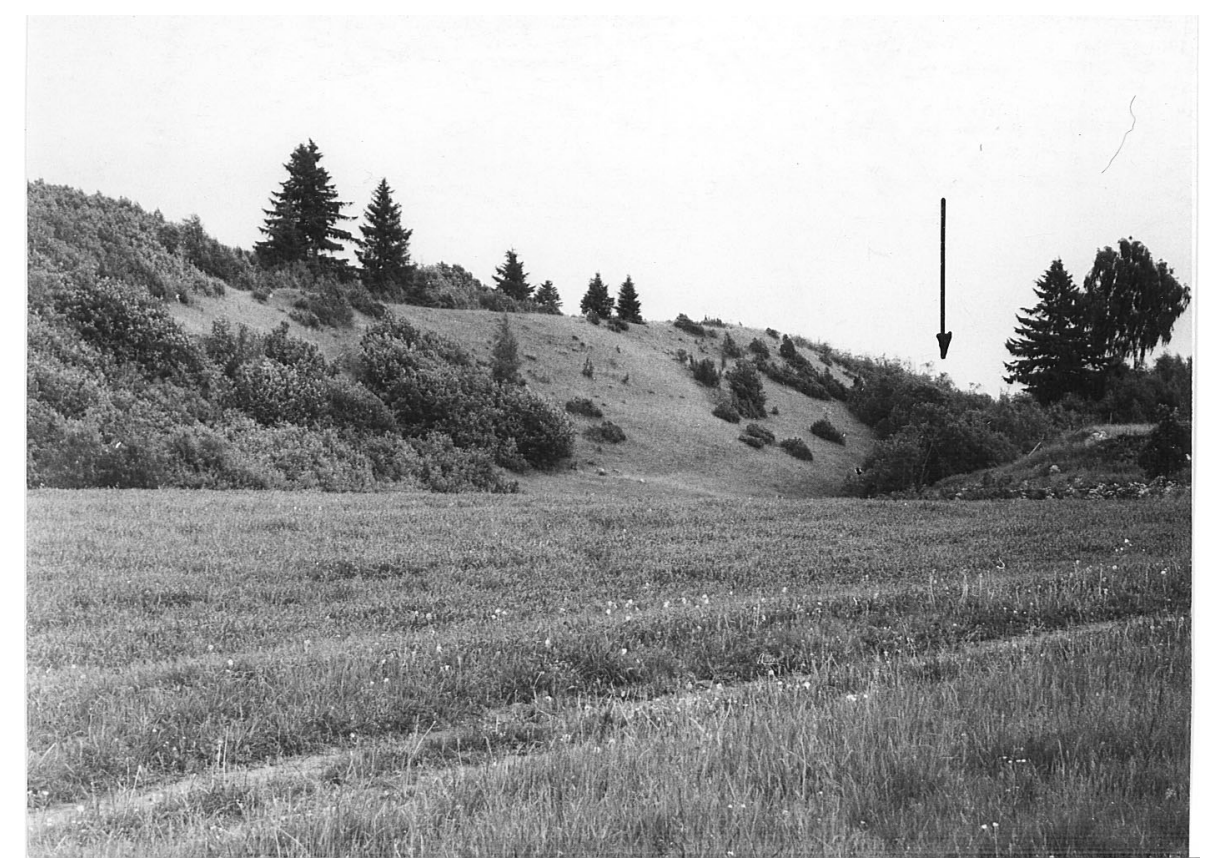

Photo 1. Pahnimägi esker (northern slope of the Pandivere Upland, Fig. 2: 7) with the esker depression (marked with the arrow) on its east side. Photo by A. Miidel.

slope or foot line of an esker (Viitna, Fig. 2: 4, and Pahnimägi esker close to Rakvere, Photo 1). When an esker is accompanied by flat-topped kames, the latter are usually located west or northwest of the esker (glaciofluvial plateau to the west from Viitna esker, Fig. 2: 4). Rähni's ideas have found confirmation in later investigations (Karukäpp 1979), but the reason for this regularity is still unclear.

The ruggedness of the relief, calculated by the total length of isohypses per square kilometre, shows that the esker systems on the background of the topography of the Pandivere Upland have a dissected relief. They are characterized by a higher level of ruggedness than any other genetic group of glacial landforms of the same upland (Karukäpp 1978).

\section{THE STRUCTURE AND DEPOSITS OF ESKERS}

Typical radial eskers of northern Estonia consist of coarse, unevenly sorted, and stratified predominantly carbonaceous ( $80 \%$ and more) glaciofluvial deposits (Photo 2). The content of the sand fraction ranges from 5 to $20 \%$ (Raukas et al. 1971; 


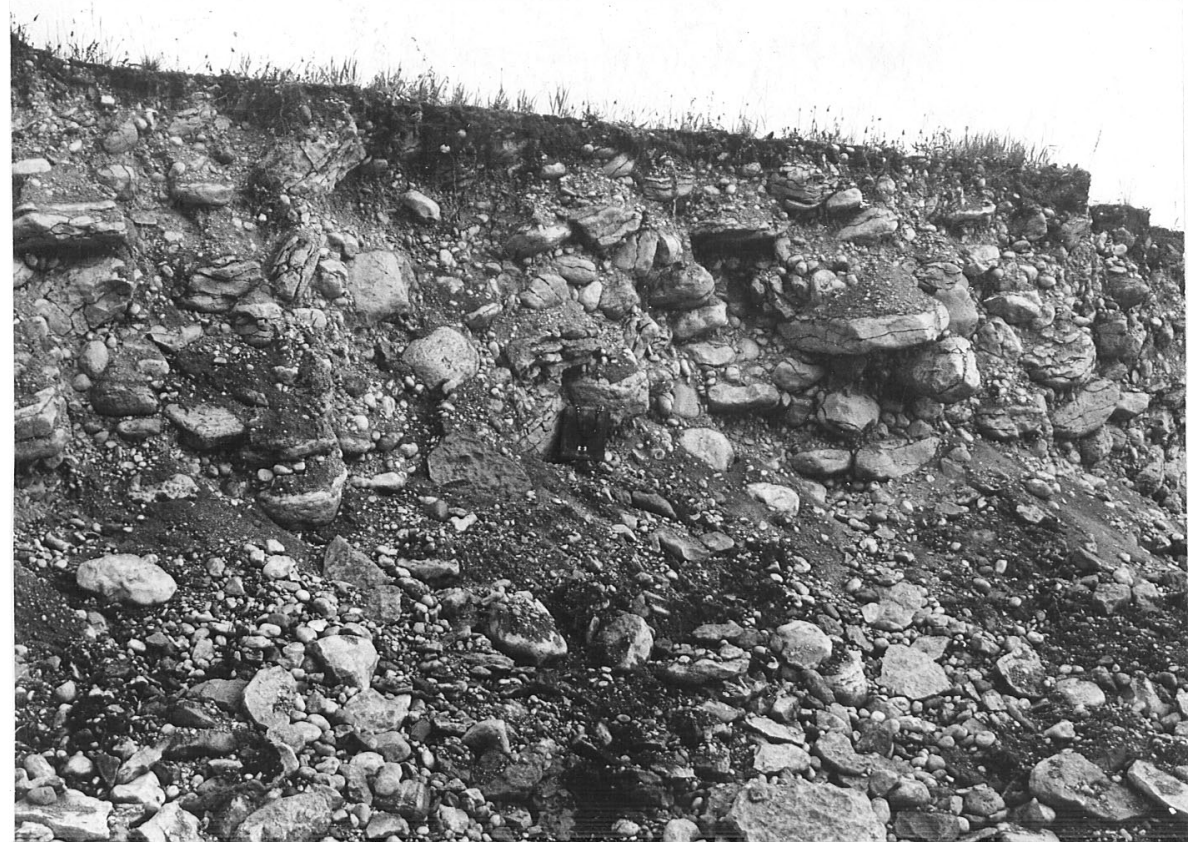

Photo 2. Coarse-grained poorly sorted carbonaceous deposits of Klinge esker (Mõdriku-Paasvere esker system, for location see Fig. 2: 6). Exposure follows the esker axis line. Photo by A. Miidel.

Raukas 1978). In some cases coarse sediments are completely unstratified. Coarse sediments are usually more abundant in the proximal part of the esker than in the distal part. Rähni $(1957,1984)$ pointed to a regularity in the esker structure: the basal layers of glaciofluvial deposits consist of finer material, while the upper and slope deposits are relatively coarse-grained. Wide flat-topped eskers, for example Aravete esker on the western slope of the Pandivere Upland (Fig. 2: 5), consist mostly of clearly stratified sand and gravel. The eskers situated in ancient valleys are, in turn, composed of better sorted deposits than these outside the valley (Raukas 1978).

Lithological analysis of the pebble-cobble fraction was carried out to establish the distance of transport of the deposits. The results of the investigations show that the glaciofluvial deposits originated from local subglacial till. Debris of the local bedrock is dominating, forming $65-85 \%$ of the pebble fraction (Raukas et al. 1971). The content of local material reaches its maximum value on the southern boundary of the bedrock outcrop and thereafter starts to decrease rapidly. The longest distance of transportation by glaciofluvial flows is $16-20 \mathrm{~km}$ for the pebble-cobble fraction. The data depend on a number of factors, such as hardness of rocks, width of the outcrop zone, bedrock topography, etc. Usually 
the content of crystalline rocks in the gravel-pebble fraction of glaciofluvial deposits is $10-15 \%$ higher than in tills, whereas the content of carbonaceous rocks in them is correspondingly lower (Raukas 1978).

\section{NEOTECTONIC MOVEMENT AND KARST PHENOMENA}

Rähni $(1973,1984)$ and Heinsalu \& Sildvee (1971) pointed to rather good correlation between the location of eskers, tectonic fault zones, and karst phenomena in sedimentary bedrock. Quite frequently springs open on the slope or foot line of eskers and karst landforms are common close to eskers. Rähni explained the genesis of eskers with direct influence of Late-Glacial tectonic movements on the bedrock-glacier association and suggested block-wise neotectonic movements with their amplitudes reaching tens of metres. According to his idea, active tectonic faults were projected and continued in the glacier and were traced by meltwater streams, in which esker deposits accumulated. Even more radical opinions have been expressed towards the tectonical genesis of the Karelian eskers: every esker outlines a tectonic fault and is completely of tectonic origin (Chuvardinskiy 1986). In Late- and Post-Glacial time the Pandivere Upland, of denudational and glacially eroded origin, underwent glacioisostatic uplift as part of the North Estonian carbonaceous plateau. The upland is intersected by six bigger zones of tectonic disturbances, trending mainly from NW to SE (Miidel \& Vaher 1997). Other smaller fault sets are of NE-SW or N-S orientation. They divide the area into several blocks of 10-20 m amplitude in height, which have almost no or very little reflection in bedrock topography. No traces of a major block corresponding to the entire Pandivere Upland have been found. The comparison of the tectonic structure and location of eskers (Karukäpp \& Tavast 1985) showed that only a few esker systems coincide with the tectonic fault zones. It is hardly probable that the streaming glacier ice, hundreds of metres in thickness, and the bedrock constitute a uniform environment for neotectonic movements, because the physical properties of glacial ice and carbonaceous rocks are too different.

Another explanation for the genesis of the complex of tectonic fault-karstesker-kettle hole-spring, which does not involve neotectonic activity is presented in Fig. 3, supposing that karst waters were active also in subglacial conditions. Subglacially active karst causes the melting of glacial sole and initiates the formation of subglacial conduits (A of Fig. 3). The next stage (B) describes the formation of open crevasses in the conditions of decreasing ice thickness. Stage $\mathrm{C}$ is characterized by intensively melting ice in the conditions of stagnant glacier. When the fluvial activity stopped (D), dead ice blocks were slowly melting under the deposits. The final stage of esker morphogenesis (E) was achieved after the melting of buried ice. Still active karst feeds a lake and springs on the slope and the foot line of the esker. 

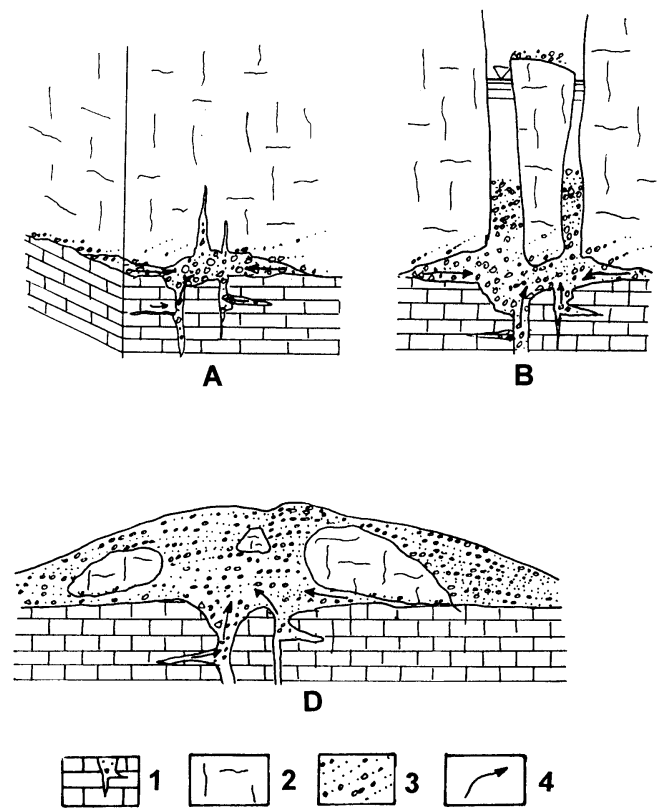
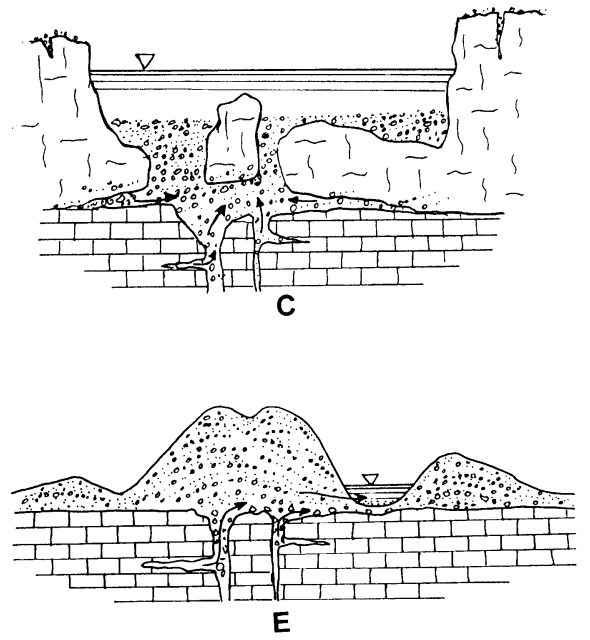

E

Fig. 3. Possible formation of an esker in connection with the subglacial faults and karst phenomena. 1 , tectonic faults in the carbonaceous bedrock; 2 , glacier ice; 3, glaciofluvial deposits; 4, direction of the karst water flow. (A) Subglacially active karst causes the melting of glacial sole and initiates the formation of subglacial conduit. (B) Glacier thickness is decreasing, open crevasses are formed and glaciofluvial erosion and deposition activated. (C) Stagnated glacier ice is intensively melting and partly covered by deposits. (D) Fluvial activity has stopped and dead ice blocks are slowly melting under the deposits. (E) Esker acquired its final morphology after the melting of ice. Karst water feeds a lake and springs on the slopes and on the foot line of the esker.

\section{DISCUSSION}

Eskers are classified as positive landforms or systems of positive landforms, complicated by kettles and often accompanied with kames, terraces or valleys (Rähni 1984). Most of the North Estonian eskers correspond to this definition (Pikasaare-Tapa, Mõdriku-Paasvere, Viitna-Ohepalu, Fig. 2: 2, 6, and 7). On the other hand, an approach to distinguish single eskers in the Neeruti esker group (Fig. 2: 1), which has been considered as consisting of classical eskers, proved unsuccessful. The topography of the Neeruti esker group may be described only through a dense pattern of elongated kettle holes cut in a large $(2 \mathrm{~km}$ long and $40 \mathrm{~m}$ high) drumlin-shape hummock (Fig. 4). Nevertheless, the morphology and deposits of individual ridges between kettles are typical of the eskers of northern Estonia.

Well-expressed ridge topography is quite frequent also in Estonia, particularly outside the aforementioned esker distribution area, for example a dense pattern of 


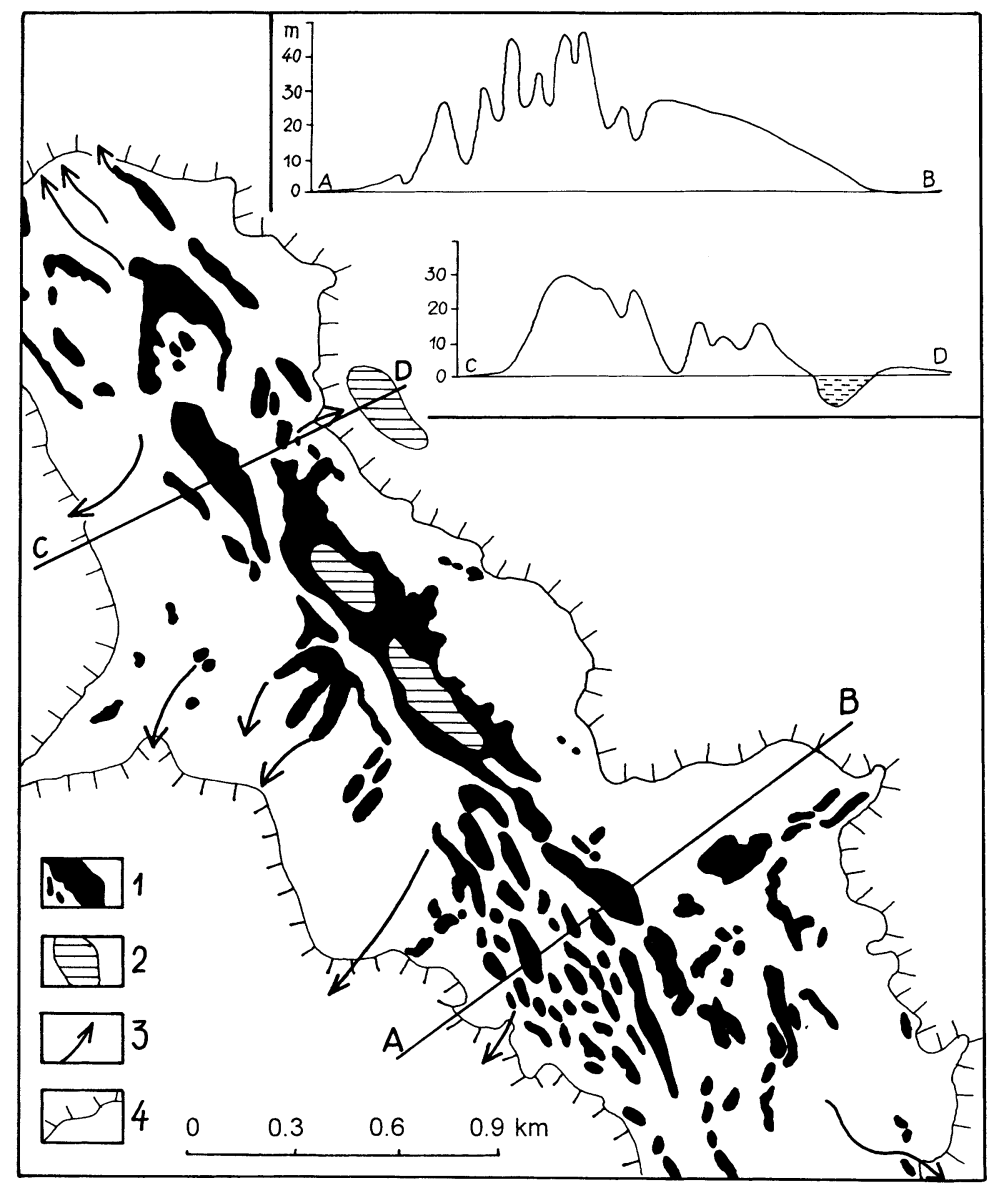

Fig. 4. The specific pattern of esker depressions and cross-sections of the Neeruti esker group (location see Fig. 2: 1). 1, esker depression; 2, lake; 3, meltwater drainage; 4, foot line of the esker group.

subparallel sand ridges in the Karula glacial complex, southern Estonia (Karukäpp 1974) and Kisejärve irregular net of ridges in the central lobe depression of the Haanja glacial accumulative heights (Karukäpp 1997). Thus, the morphological characteristics alone do not define a morphogenetical esker. Already Flint (1928) pointed out the necessity to distinguish real eskers from other ridge-like formations. For example, irregularly located ridges, formed in crevasses of stagnant ice, are specified as crevasse fillings (Flint 1928). The latter associate with kames or socalled pitted outwash plains and consist of moderately fine deposits with more or less horizontal bedding. The genesis of these complexes is connected with accumulation in stagnant ice. The pattern of the glacier crevasses was either regular (controlled by previous ice stream direction) or irregular (uncontrolled by glacial dynamics). 
The esker formation is determined by the distribution of the thawed-bed glacier. As the territory of Estonia belonged entirely to the area where subglacial temperature exceeded the melting point, even during the maximum of the last glaciation (LGM) (Kleman \& Hättestrand 1999), the initial stage of esker formation could have started already ca 18 000-20 000 years ago. But the eskers got their final shape only after the melting of stagnant ice and buried ice blocks. In spite of the long-lasting genesis of the esker systems, the accumulation of glaciofluvial deposits, erosion and redeposition of a single esker was a very rapid process. Several approaches were made to estimate the relative time of final esker formation. One of those is based on the linear repetition of esker segments (beaded eskers), which refers to the cyclicity of ice melting and its possible connection with climate. The signals of three cycles can be traced. Beside the seasonal 1-year cycle, the 3-6- and 11-year cycles have been registered. The latter circumstance supports the effect of the sunspot cycle (Lundqvist 1999). According to Lundqvist (1999), the 3-6-year period is connected to the El Niño-Southern Ocean (ENSO) phenomenon.

Rähni (1984) described layering cycles and rhythms in the esker deposits. Usually 6-8 rhythms of the alternation of coarse and finer glaciofluvial material can be observed in the North Estonian eskers. The esker centres, described by Rähni (1984) as regularly repeated higher tops along the esker crest, correspond to beaded esker by Warren \& Ashley (1994). These centres consist usually of coarse, poorly sorted cobbles, pebbles, and gravel and serve as the indicators of cyclicity.

The basal layers of North Estonian eskers usually consist of finer deposits than the upper portion. The horizontally bedded deposits are finer than cross-bedded ones. One or two horizontal interlayers of fine sand or even loam can be traced in the lower part of several eskers, being thus indicative of periodical changes in subglacial flow (Rähni 1984).

It is noteworthy that almost all Estonian esker systems end very abruptly in the North or Northwest (in proximal parts) and are gradually lowering in the distal direction. To explain this morphological peculiarity, further studies are needed.

\section{CONCLUSIONS}

Eskers as linear systems of landforms of glaciofluvial sedimentation require certain preconditions for genesis:

1. Thaw-based glacier on the nonpermeable subglacial surface.

2. More or less stable subglacial or englacial conduit systems.

3. The existence of subglacial tectonic faults and valleys, which coincided with the glacier flow direction, but esker formation was not a direct result of the Late-Glacial neotectonic movement in the glacial-subglacial environment. 
The structure and stratification of esker deposits, as well as cyclic changes in morphology, indicate a fast erosion-transportation-sedimentation process, but the formation of an esker system as a whole was most likely time-transgressive, lasted thousands of years, and completed with final melting of stagnant and buried ice. In view of the above, revision of the definition and classification of eskers is needed. In addition to the eskers occurring as isolated positive landforms, a net of ridges between kettles (e.g. Neeruti eskers) should also be considered as eskers. Ridges of glaciofluvial deposits, which were formed during relatively short time in stagnant ice crevasses, serve as crevasse fillings and are genetically closer to kames and should be specified as kame ridges.

\section{ACKNOWLEDGEMENTS}

I am obliged to my long-term colleagues Endel Rähni, Anto Raukas, and Avo Miidel with whom I have studied Estonian eskers during many years and have had fruitful debates. I am indebted to the reviewers Avo Miidel and Tiit Hang for useful suggestions and to Helle Kukk for linguistic help. The research was supported by the Estonian Science Foundation (grant No. 5342) and Estonian State Target Foundation (project No. 0331759s01).

\section{REFERENCES}

Benn, D. I. \& Evans, D. I. A. 1998. Glaciers and Glaciations. Arnold, London.

Boulton, G. S., Caban, P. E., van Gijssel, K., Leinsje, A., Punkari, M. \& van Weert, F. H. A. 1996. The impact of glaciation on the groundwater regime of Northwest Europe. Global Planet. Change, 12, 397-413.

Chuvardinskiy, V. G. 1986. About the tectonical origin of the eskers. In Problemy termomekhaniki gruntov, pp. 82-92. Institut mekhaniki MGU, Moscow (in Russian).

Eilart, J. 1988. Kalevipoja künnimaadel. Horisont, 2, p. 29.

Flint, R. F. 1928. Eskers and crevasse fillings. Am. J. Sci., 235, 410-416.

Heinsalu, Ü. \& Sildvee, H. 1971. Die Abhängigkeit der neotektonischen und der gegenwärtigen differenzierten Bewegungen im nordöstlichen Estland von den Störungszonen des Grundgebirges und der Tafeldecke. Eesti NSV Tead. Akad. Toim. Keemia. Geol., 20, 260-265 (in Russian).

Huddardt, D., Bennett, M. R. \& Glasser, N. F. 1999. Morphology and sedimentology of a higharctic esker system: Vegbreen, Svalbard. Boreas, 28, 253-273.

Karukäpp, R. 1974. Karula kõrgustiku reljeefist. In EGS-i aastaraamat 1973, pp. 36-51. Tallinn.

Karukäpp, R. 1978. Morphological peculiarities of the kame fields of the Estonian glacial uplands. In Stroenie i formirovanie kamov (Raukas, A., ed.), pp. 84-91. Academy of Sciences of ESSR, Tallinn.

Karukäpp, R. Ya. 1979. Osobennosti formirovaniya chetvertichnogo pokrova $i$ form rel'efa $v$ gotiglyatsial'nom étape deglyatsiatsii (na primere territorii Éstonii). Abstract of Candidate's thesis. Vilnius State University, Vilnius (in Russian). 
Karukäpp, R. 1997. Gotiglatsiaalne morfogenees Skandinaavia mandriliustiku kagusektoris. $\mathrm{PhD}$ thesis. Tartu Ülikooli Kirjastus, Tartu.

Karukäpp, R. \& Tavast, E. 1985. Tectonic structure and glacial morphogenesis of Pandivere Upland. Proc. Acad. Sci. Estonian SSR Geol., 34, 22-29 (in Russian).

Kleman, J. \& Hättestrand, G. 1999. Frozen-bed Fennoscandian and Laurentide ice sheets during the Last Glacial Maximum. Nature, 402, 4, 63-66.

Lundqvist, J. 1999. Scandinavian eskers, global climatic relationships, and solar forcing. Geol. Quarterly, 43, 149-152.

Miidel, A. \& Vaher, R. 1997. Neotectonics and recent crustal movements. In Geology and Mineral Resources of Estonia (Raukas, A. \& Teedumäe, A., eds.), pp. 177-180. Estonian Academy Publishers, Tallinn.

Motuza, G. \& Motuza, V. 1999. Kalevo sūnaus pedom. Geologijos akiračiai, 2, 35-41.

Nye, J. F. 1973. Water at the bed of glacier. In Symposium on the Hydrology of Glaciers. IASH Publ., 95, 189-194.

Pirrus, E. 1997. Book of Primeval Nature. In Geology and Mineral Resources of Estonia (Raukas, A. \& Teedumäe, A., eds.), pp. 375-377. Estonian Academy Publishers, Tallinn.

Punkari, M. 1994. Subglaasialinen hydrologia harjunen synnyn selitäjänä. Geologi, 1, 3-6.

Punkari, M. 1997. Subglacial processes of the Scandinavian Ice Sheet in Fennoscandia inferred from flow-parallel features and lithostratigraphy. Sedim. Geol., 111, 263-283.

Raukas, A. 1978. Pleistocene Deposits of the Estonian SSR. Valgus, Tallinn (in Russian).

Raukas, A. 1998. Vallseljakud - kõige eestilikumad pinnavormid. Eesti Loodus, 5/6, 264-265.

Raukas, A., Rähni, E. \& Miidel, A. 1971. Kraevye lednikovye obrazovaniya Severnoj Éstonii. Valgus, Tallinn (in Russian).

Rähni, E. 1957. About the morphology of eskers of Pandivere Upland, Estonian SSR. Nauchnye soobshcheniya Inst. geol. i geogr. AN Litovskoj SSR, 14, 363-369 (in Russian).

Rähni, E. E. 1967. Ozy i kraevye obrazovaniya poslednego oledeneniya na Pandivereskoj vozvyshennosti (Éstonskaya SSR). Abstract of Candidate's thesis. Akad. Nauk ÉSSR, Tallinn (in Russian).

Rähni, E. 1973. On the neotectonic block movements of the Earth's crust on the territory of Estonia. Eesti NSV TA Toim. Geol., 22, 331-340 (in Russian).

Rähni, E. 1984. Kuidas tekkisid oosid? Eesti Loodus, 1, 28-35.

Röthlisberger, H. 1972. Water pressure in intra- and subglacial channels. J. Glaciol., 11, 177-203.

Warren, W. P. \& Ashley, G. M. 1994. Origin of the ice contact stratified ridges (eskers) of Ireland. J. Sedim. Res., A64, 433-449.

\section{Oosid nende levikuala perifeerias Põhja-Eestis}

\section{Reet Karukäpp}

Oosid on paleoliustiku kulutusalale iseloomulikud pinnavormid. Nende kujunemise vajalikuks eeltingimuseks olid sulapõhjaline liustik, vett mitte läbi laskev liustikualune pind ja enam-vähem stabiilsed liustikualused või -sisesed sulamisvee vooluteed. Voolusuund jälgis reeglina liustiku pealispinna kallet, moodustades radiaalsete ooside süsteeme. Oosisüsteemide kümnetesse või isegi sadadesse kilomeetritesse ulatuv pikkus näitab nende tekke pikaajalisust. Seejuures pärineb 
ooside nüüdisaegne kuju nende kõige hilisemast arengustaadiumist - irdjää ja mattunud jää lõpliku sulamise ajast.

Nüüdisliustike uurimistulemused näitavad settimise, materjali transpordi ja kulutuse kiiret vaheldumist oosi kujunemise käigus ja kinnitavad seisukohta, et oosi morfoloogia ja setete struktuur erineb suuresti esialgse liustikutunneli kujust ja suunast ning setete lasumusest.

Eesti asub Skandinaavia jäätumise ooside leviala perifeerias (joon 1) ja ooside tekkeks vajalikud tingimused olid vaid Põhja-Eestis (joon 2), kus vett vähe läbi laskvad Paleosoikumi karbonaatsed kivimid olid liustikualuseks pinnaks. PõhjaEesti oosid koosnevad peamiselt jämedapurdseist setetest, milles domineerivad kohaliku aluspõhja settekivimid. Iseloomulikud on ooside, oosilohkude ja -mõhnade või liustiku sulamisveetekkeliste lavade kooslused.

Nii ooside levikualal kui ka väljaspool seda esinevad valli- või seljakukujulised pinnavormid, mille kujunemine sai alguse irdjää lõhedes, on küll morfoloogiliselt oosidesarnased, kuid geneetiliselt seotud mõhnadega. 